\title{
PENERAPAN SISTEM INFORMASI PEMBERITAHUAN IMPOR BARANG KHUSUS BERBASIS WEB DENGAN METODE WATERFALL PADA KPPBC TMP SOEKARNO - HATTA
}

\author{
IRPAN KUSYADI \\ Teknik Informatika Universitas Pamulang \\ JL. Surya Kencana No. 1, Pamulang, Tangerang Selatan-Indonesia \\ email : dosen00673@unpam.ac.id
}

\begin{abstract}
ABSTRAK
Impor merupakan suatu proses transportasi barang atau komoditas dari suatu negara ke negara lain secara legal, umumnya dalam proses perdagangan. Proses impor umumnya adalah tindakan memasukan barang atau komoditas dari negara lain ke dalam negeri. Kegiatan impor barang khusus dilakukan dengan cara mengisi form pemberitahuan impor barang khusus secara manual, kemudian selanjutnya dilakukan pemeriksaan secara langsung di dalam form tersebut. Proses dokumentasi dan pengarsipan dokumen PIBK yang telah selesai diproses dilakukan secara manual bahkan dokumen PIBK tidak terdokumentasi, sehingga untuk mencari suatu dokumen harus dicari satu persatu dari sekumpulan dokumen di dalam gudang. Laporan impor barang khusus dan penerimaan dari kegiatan impor barang khusus tersebut harus dilaporkan secara periodik. Dan untuk membuat laporan tersebut dilakukan secara manual dengan menuliskannya ke dalam bentuk file Microsoft Excell. KPPBC TMP Soekarno - Hatta merupakan suatu kantor Pengawasan dan Pelayanan Bea dan Cukai yang mengalami masalah tersebut, maka diperlukan suatu sistem informasi pemberitahuan impor barang khusus (PIBK). Sistem dikembangkan dengan menggunakan metodologi waterfall yang terbagi atas tujuh tahap yaitu definisi kebutuhan sistem, definisi kebutuhan software, analisis, perancangan sistem, implementasi serta integrasi dan pengujian sistem dan pengopeasian sistem. Sedangkan bahasa pemrograman yang digunakan adalah PHP dan dipadukan dengan database MySql. Sistem yang dikembangkan perlu diuji dengan pengujian Blackbox dan Whitebox sehingga hasil pengembangan dapat sesuai dengan yang telah diharapkan.
\end{abstract}

\section{PENDAHULUAN}

KPPBC TMP Soekarno-Hatta merupakan suatu Kantor Pengawasan dan Pelayanan Bea dan Cukai yang terletak di kawasan Bandara Soekarno-Hatta. Dimana dalam kesehariannya melayani kegiatan Ekspor dan Impor barang khusus $(<100 \mathrm{~kg})$ untuk Perusahaan Jasa Titipan (PJT) dan Petugas Pengguna Jasa Kepabeanan (PPJK).

Dalam 5 tahun terakhir, terjadi peningkatan jumlah transaksi impor barang khusus yang harus dilayani. Pada umumnya, untuk mengurus pengeluaran barang impor barang khusus tersebut, dilakukan dengan menggunakan proses manual, sehingga dapat menghambat pemeriksaan terhadap barang ataupun dokumen pemberitahuan impor barang khusus. Setiap hari, dokumen yang harus diperiksa dapat mencapai 1000 (seribu) dokumen, sedangkan untuk menyelesaiakan satu dokumen dibutuhkan waktu sampai 5 hari, dan dokumen yang telah diperiksa belum terdokumentasi dengan baik. Hal ini dapat menyulitkan pencarian dokumen ketika dokumen tersebut dibutuhkan kembali untuk keperluan audit yang dilakukan oleh BPK ataupun untuk keperluan lainnya. KPPBC Soekarno-Hatta juga mengalami kesulitan dalam pembuatan laporan bulanan untuk Pemberitahuan Impor barang khusus kepada Kantor Pusat Bea dan Cukai. Masalah lain adalah kesulitan dalam hal rekonsiliasi besarnya penerimaan yang didapat dari proses Impor barang khusus tersebut.

Penelitian ini akan merancang dan mengaplikasikan terkait tentang Sistem Informasi Pemberitahuan Impor Barang Khusus pada KPPBC TMP Soekarno Hatta berbasis web, yang diharapkan dapat membantu untuk mengatasi segala permasalahan dalam rangka impor barang khusus. 


\section{METODE PENELITIAN}

Metode rekayasa peranti lunak yang digunakan peneliti adalah Metode waterfall. Menurut Pressman (2010, p.39) waterfall adalah model klasik yang bersifat sistematis, berurutan dalam membangun software. Berikut ini ada dua gambaran dari waterfall model.

Fase-fase dalam model waterfall menurut referensi Pressman:

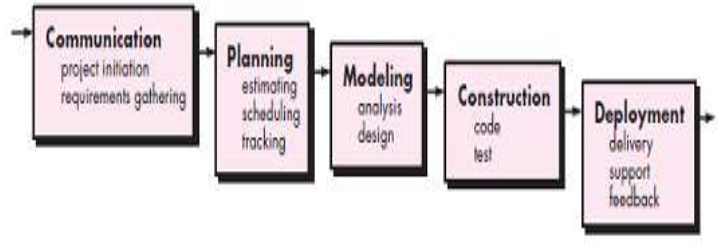

Gambar 2. 1 Model Waterfal (Pressman, 2010, p.39)

a. Communication

Langkah ini merupakan analisis terhadap kebutuhan software, dan tahap untuk mengadakan pengumpulan data dengan melakukan pertemuan dengan customer, maupun mengumpulkan data-data tambahan baik yang ada di jurnal, artikel, maupun dari internet.

b. Planning

Proses planning merupakan lanjutan dari proses communication (analysis requirement). Tahapan ini akan menghasilkan dokumen user requirement atau bisa dikatakan sebagai data yang berhubungan dengan keinginan user dalam pembuatan software, termasuk rencana yang akan dilakukan.

c. Modeling

Proses modeling ini akan menerjemahkan syarat kebutuhan ke sebuah perancangan software yang dapat diperkirakan sebelum dibuat coding. Proses ini berfokus pada rancangan struktur data, arsitektur software, representasi interface, dan detail (algoritma) prosedural. Tahapan ini akan menghasilkan dokumen yang disebut software requirement.

d. Construction

Construction merupakan proses membuat kode. Coding atau pengkodean merupakan penerjemah desain dalam bahasa yang bisa dikenali oleh komputer. Programmer akan menerjemahkan transaksi yang diminta oleh user. Tahapan inilah yang merupakan tahapan secara nyata dalam mengerjakan suatu software, artinya penggunaan komputer akan dimaksimalkan dalam tahapan ini. Setelah pengkodean selesai maka akan dilakukan testing terhadap sistem yang telah dibuat tadi. Tujuan testing adalah menemukan kesalahan - kesalahan terhadap sistem tersebut untuk kemudian bisa diperbaiki.

e. Deployment

Tahapan ini bisa dikatakan final dalam pembuatan sebuah software atau sistem. Setelah melakukan analisis, desain dan pengkodean maka sistem yang sudah jadi akan digunakan oleh user. Kemudian software yang telah dibuat harus dilakukan pemeliharaan secara berkala.

\section{PEMBAHASAN \\ Analisa Sistem Berjalan}




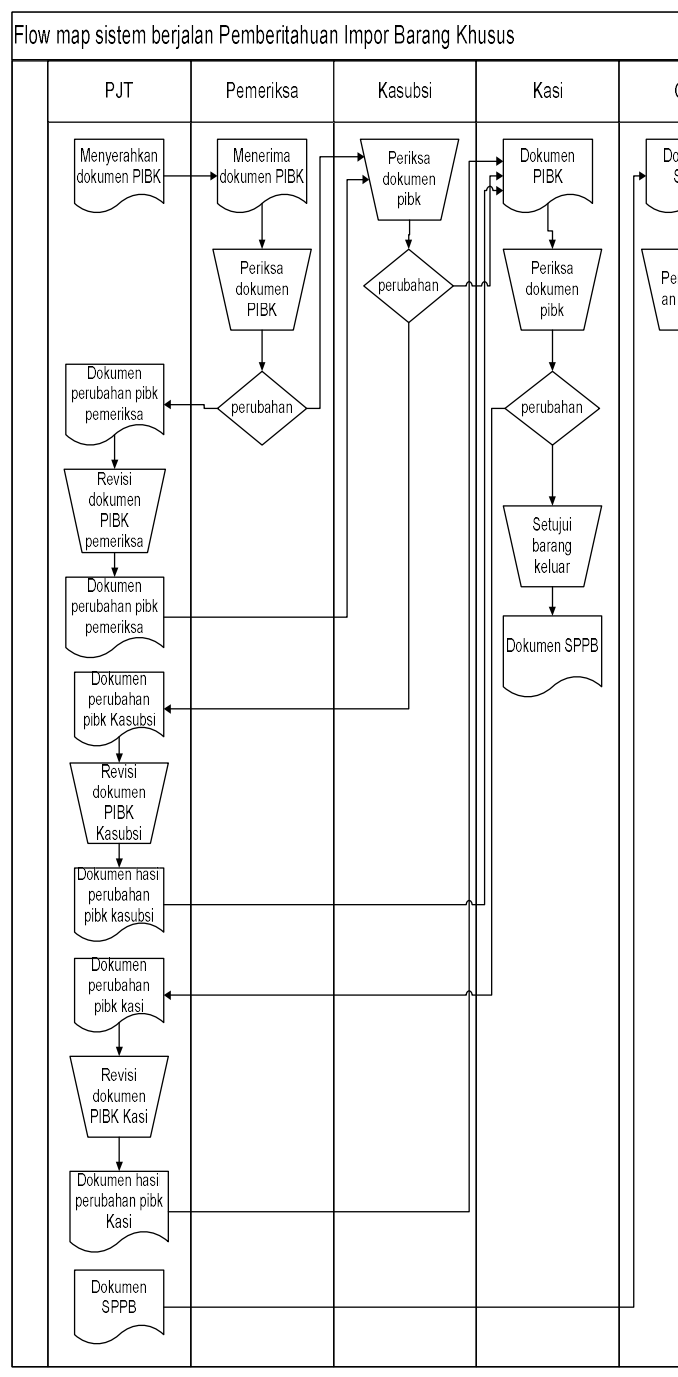

\section{Analisa Kebutuhan}

Pada analisis kebutuhan, penulis menggunakan diagram use case dan tabel glosarium use case untuk mengidentifikasi kebutuhan kebutuhan yang dibutuhkan. Tujuan pembuatan use case ini adalah untuk menganalisis dan mendapatkan kebutuhan-kebutuhan yang tepat untuk membangun sebuah sistem. Berikut ini diagram use case pada pengambangan sistem informasi PIBK pada KPPBC TMP Soekarno Hatta.

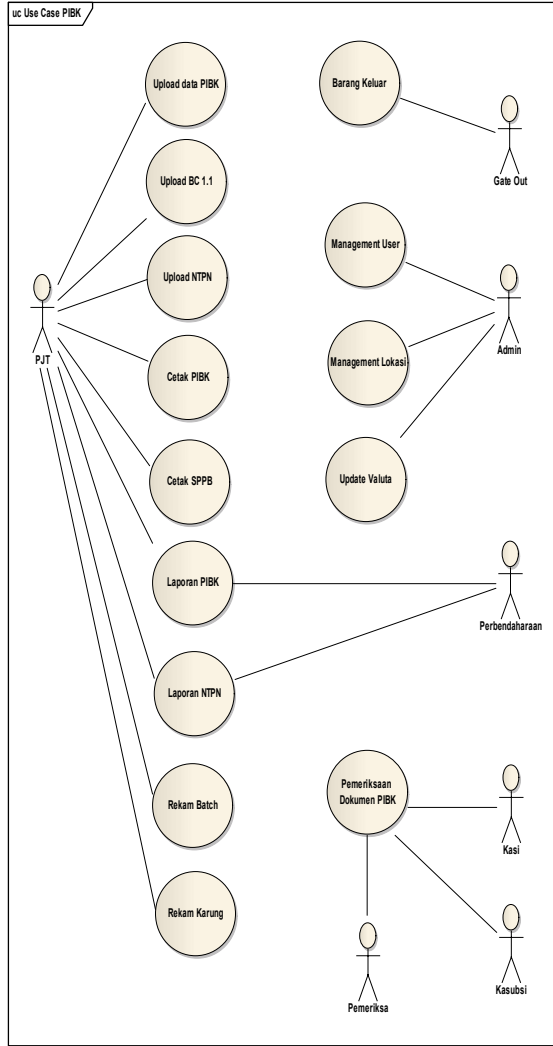

4. KESIMPULAN

Dengan melakukan setiap tahapan waterfall tersebut maka aplikasi pemperitahuan impor barang khusus pada KPPBC TMP Soekarno hatta dapat dikembangkan dan diterapkan. Dengan menggunakan Aplikasi Pemberitahuan Impor Barang Khusus tersebut, maka masalah yang terjadi dapat dipecahkan. Yaitu, untuk pemeriksaan dan pembuatan dokumen impor barang khusus tidak diperlukan waktu yang lama. Untuk menyelesaikan satu dokumen hanya dibutuhkan waktu 1 hari. Dokumen yang telah diselesaikan telah didokumentasikan dengan baik, sehingga memudahkan untuk pencarian dokumen jika dibutuhkan kembali. Proses pembuatan laporan bulanan terkait impor barang khusus dapat dilakukan dengan mudah, karena mempunyai menu tersendiri di dalam aplikasi untuk membuatnya. Petugas perbendaharaan dapat dengan mudah melakukan proses rekonsiliasi, karena proses tersebut telah dibantu dengan menggunakan aplikasi.

\section{SARAN}


Penulis menyadari bahwa sistem informasi pemberitahuan impor barang khusus (PIBK) dengan menggunakan model waterfall ini masih terdapat beberapa kekurangan, adapun saran yang dapat diberikan antara lain :

a. Sistem informasi pemberitahuan impor barang khusus ini diharapkan dapat terhubung dengan aplikasi $e$ Billing kantor Pusat Bea dan Cukai, untuk verifikasi pembayaran.

b. Sistem informasi pemberitahuan impor barang khusus ini diharapkan dapat terhubung dengan Indonesian National Single Window (INSW), agar pengawasan terhadap barang barang ekspor dan impor dapat dilakukan dengan lebih baik lagi.

\section{DAFTAR PUSTAKA}

[1] Debbabi, Hassaine, et. Al., (2010). Verification and Validation in System Engineering : Assesing UML/SysML Design Models. New York: Springer.

[2] Dwi Nurcahyo, Agustiansyah Riza, Pengembangan Sistem Informasi Manajemen Rekapitulasi Laporan Rekam Medis Rumah Sakit Kepada Dinas Kesehatan Kab/Kota Berdasar Ketentuan Kementrian Kesehatan Republik Indonesia Menggnakan Metode Waterfall, 2012.

[3] Indriasari Sofiyanti, Sistem Informasi Berbasis Web Untuk Membantu Kegiatan Tracer Study Program Diploma Institute Pertanian Bogor, Vol.2, 2012.

[4] Keyes, J. (2005). Software Engineering Handbook (A CRC Press Company ed.). Auerbach Publications.

[5] Kumaladewi Nia, Hidayah Nur Aeni dan Amalia Rizki, Sistem Informasi Akuntansi Pengeluaran Kas (Studi Kasus : BNI Syariah Fatmawati), Seminar Nasional Aplikasi Teknologi Informasi, 2011 (SNATI 2011), ISSN: 1907-5022

[6] Laudon, K. C., \& Price, L. J. (2011). Essentials of Management information Systems. Boston: Prentice Hall.

[7] McLeod (2004). Sistem Informasi Manajemen. PT. Indeks. Jakarta

[8] Melian Lusi dan Hilman Agus, Perancangan dan Pembangunan Sistem Informasi Geografis Pariwisata Di Kota Bandung Berbasis Websaite, Vol. 1 UNIKOM, 2013.

[9] O’Brien, James A., dan Marakas, George M., (2008). Management Information System. McGraw-Hill., Copyright 2008.
[10] O’Brien \& Marakas. (2009). Introduction to Information Systems, 15th Edition. McGrawHill/Irwin.

[11] O’Brien \& Marakas. (2010). Management Information Systems, 10th Edition. McGraw-Hill Higher Education.

[12] Purnama Agung Rizki, Aristoteles dan Widiarti, Analisis dan Pengembangan Sistem Informasi Rapor Online Berbasis Mobile pada SMA Negeri 1 Gedng Tataan, Jurnal Komputasi, Desember 2012, Vol 1, No.1

[13] Royce W. Winston, Managing The Development Of Large Software Sysem, The Institute of Electronics Engineers, 1970.

[14] Rubianto IM, Nurwandi Luthfi, Gunandi Erwin, Pemodelan Sistem Perpustakaan Metode Pengembangan Tradisional Waterfall, Studi Kasus Di SMAN 6 Garut, STT Garut, 2012.

[15] S.Pressman, R. (2010). Software Engineering A Practitioner's Approach 7th Edition. McGraw-Hill Higher Education.

[16] Sommervile, I. (2011). Software Engineering nineth edotion. Massachusetts: Pearson Education, Inc., publishing as AddisonWesley

[17] Stair, Ralph M. \& George W. Reynolds (2010). Information System Canada: Course Technology Cengage Learning. (2010) 